\title{
PENINGKATAN INCOME GENERATE MELALUI UNIT USAHA COUNCELING CENTRE BERBASIS INTELEKTUAL KAMPUS
}

\author{
Rosmala Dewi ${ }^{1}$, Muhammad Bukhori Dalimunthe ${ }^{2^{*}}$ \\ ${ }^{1}$ Jurusan Psikologi Pendidikan dan Bimbingan, Fakultas Ilmu Pendidikan, Universitas Negeri Medan \\ ${ }^{2}$ Jurusan Pendidikan Ekonomi, Fakultas Ekonomi, Universitas Negeri Medan \\ Jl. Willem Iskandar pasar V-Kotak Pos No. 1589 - Medan 20221 \\ *Penulis korespondensi: daliori86@unimed.ac.id
}

\begin{abstract}
Abstrak
Counseling centre Universitas Negeri Medan, yang disebut juga sebagai COCE, memiliki tujuan untuk memperoleh pendapatan dan menciptakan wirausaha baru yang dikelola dosen dan mahasiswa. COCE menyediakan pelayanan mutu peminatan di sekolah. Pelayanan dilakukan dengan cara holistik, kreatif, inovatif, cepat, tuntas, pantas, dan baik. Pengelolaan manajemen menggunakan managemen mutu sehingga lebih mengutamakan strategi pemberdayaan dari pada birokrasi. Teknik pemasaran usaha ini dimulai dengan sosialisasi melalui penyebaran brosur dan infromasi melalui radio, harga bersaing, promosi, dan penentuan posisi. Klien COCE berasal dari siswa dan mahasiswa yang mengalami masalah dalam belajar yang berlokasi di Propinsi Sumatera Utara. Hasil pelayanan tes pada tahun pertama (2015) yang telah dilakukan COCE melayani 4.127 klien dan margin keuntungan operasi diperoleh sebesar 91,07\%. Pada tahun kedua (2016), pelaksanaan tes yang dilakukan COCE telah memberikan pelayanan sebanyak 3.659 klien dan margin keuntungan sebesar 86,99\%. Bentuk pelayanan yang diberikan berupa layanan konseling, psikotes, dan bimbingan belajar.
\end{abstract}

Kata kunci: income generate, counseling centre, intelektual kampus.

\begin{abstract}
Counseling center at Medan State University, also known as COCE, has a goal to earn income and create new entrepreneurship managed by lecturers and students. COCE provides quality services in schools and colleges. The service is done in a holistic, creative, innovative, quick, exhaustive, proper, and excellent. Management management uses quality management so as to prioritize empowerment strategy rather than bureaucracy. This business marketing technique begins with socialization through the spread of brochures and information via radio, competitive prices, promotion, and positioning. COCE clients come from students and students who have learning problems located in North Sumatra Province. The results of the test service in the first year (2015) that has been conducted COCE serves 4.127 clients and operating profit margin is $91,07 \%$. In the second year (2016), the implementation of tests conducted COCE has provided service for 3,659 clients and profit margin of $86.99 \%$. Form of services provided in the form of counseling services, psychology, and tutoring.
\end{abstract}

Keywords: income generate, counseling centre, campus intellectuals.

\section{PENDAHULUAN}

Usaha pelayanan jasa konseling, psiko tes, dan bimbingan belajar yang memiliki keungulan pelayanan professional, holistik dan inovatif berbasis teknologi dilaksanakan dengan cepat, pantas dan hasil excellent disebut nama unit usaha Counseling Center atau dikenal juga sebagai COCE. Keberadaan COCE dibentuk berdasarkan Surat Keputusan Rektor Universitas Negeri Medan nomor 0063/UN33.KEP/KP/2011 untuk dapat memaksimalkan pelayanan serta peningkatan income generate kampus. Kompetitor unit usaha ini adalah biro psikologi, selama ini hasil tes psikologi yang dilaksanakan oleh psikolog belum cukup membantu dan bermanfaat untuk diterjemahkan menjadi program pelayanan pendidikan dan pembelajaran bagi guru bidang studi dan guru bimbingan konseling. Sedangkan, jumlah siswa yang mengalami masalah dalam belajar, pribadi, sosial, karir, keluarga, dan keberagamaan semakin meningkat. Permasalahan siswa di sekolah berupa perkelahian, tauran, ganja, dan pelecehan seksual. Peristiwa SMKN 2 Kota Makassar seorang guru dipukul orang tua siswa dan muridnya mengakibatkan guru tersebut harus menjalani operasi 
hidung dikarenakan guru menegur siswa yang tidak mengerjakan pekerjaan rumah (Kompas, 2016). Tindakan pelajar dan mahasiswa sekarang mengarah pada tindakan kriminal dan pembunuhan. Tindakan mahasiswa Universitas Muhammadyah Sumatera Utara membunuh dosennya di kamar mandi (Antaranews, 2016). Sebagian besar pelaku kejahatan tersebut adalah pelajar dan mahasiswa. Proses pembelajaran pada tingkat Perguruan Tinggi juga mengalami permasalah bagi mahasiwa. Perubahan iklim belajar dari jejang pendidikan menengah ke pendidikan tinggi menyulitkan mahasiswa untuk beradaptasi. Hasil penelitian yang dilakukan Dewi (2012) mahasiswa Universitas Negeri Medan memiliki permasalahan belajar tertinggi yaitu masalah keterampilan belajar dan diri pribadi.

Mengingat perkembangan permasalahan siswa dan mahasiswa yang memprihatinkan tersebut tim merancang COCE sebagai tempat konsultasi, konseling, dan tes psikologi untuk kepentingan pendidikan remaja. Bagi orang tua, guru, kepala sekolah, Yayasan Pendidikan yang ingin mendapatkan pelayanan konsultasi, konseling, tes psikologi tentang anaknya. Peran konselor semakin kompleks dengan permasalahan yang dihadapi oleh siswa dan mahasiswa. Dewi (2013) menjelaskan bahwa model pelayanan konseling sebaya saat ini sangat dibutuhkan mahasiswa. Teman sebaya dapat berperan sebagai konselor sebaya untuk membantu teman yang bermasalah. Unit usaha COCE menyediakan akses belajar bagi siswa dan mahasiswa yang berminat menjadi konselor sebaya.

Spesifikasi produk COCE melaksanakan pelayanan konseling, tes psikologi, pengukuran mutu dan masalah belajar, semua data tersebut berguna dalam rangka membantu siswa yang bermasalah dalam perkembangan, belajar dan penentuan peminatan sesuai dengan kurikulum 2013. Pada kegiatan peminatan digunakan data nilai raport, prestasi non akademik, permintaan siswa dan orang tua, hasil tes psikologi. Bagi siswa dan mahasiswa yang bermasalah dilaksanakan pelayanan konseling secara profesional. Bagi siswa dan mahasiswa yang mengalami kesulitan berhubungan dengan bidang studi diberikan bimbingan belajar dari dosen bidang studi yang ada di jurusan seperti; Matematika, Bahasa Indonesia, Bahasa Inggris, IPA, IPS. sesuai kebutuhan kompetensi siswa. Spesifik yang lain COCE melaksanakan pelayanan di sekolah memberdayakan guru bimbingan konseling tentang tugasnya sebagai pembimbing melaksanakan konseling secara professional, data yang lengkap dan menyeluruh, pelayanan yang cepat dan tuntas membantu siswa menentukan bidang minatnya dengan cara-cara yang dapat membangun karakter yang baik.

\section{METODE PELAKSANAAN KEGIATAN}

Metode pelaksanaan kegiatan dilakukan langkah-langkah sebagai berikut; (1) sosialisasi COCE ke sekolah-sekolah, dan kantor Dinas Pendidikan Kabupaten/Kota; (2) penyusunan MoU dan Surat Perjanjian Kerja antar COCE Universitas Negeri Medan dan instansi yang telah bersedia menerima layanan; (3) pelaksanaan tes inteleigensi, bakat, minat, mutu dan masalah belajar; (4) skoring; (5) pengumpulan data mentah dan strandar; (6) analisis data; (7) penulisan rekomendasi; (8) penyusunan laporan; (9) penyampaian hasil tes ke instansi; (10) penyusunan program layanan konseling dan implementasi pada anak-anak; dan (11) laporan hasil pelaksanaan program layanan konseling. Pelayanan COCE dapat terlaksana dikarenakan dukungan berbagai komponen, diantaranya;

1. Bahan baku, sumber perolehan klien dari ikatan alumni mahasiswa PPK Universitas Negeri Medan, sebagai guru BK SLTP dan SLTA dari Kota Medan, Kota Binjai, Kabupaten Deli Serdang, kabupaten Asahan, dan Kabupaten Tanah Karo. Konselor berjumlah 30 orang dilibatkan pada COCE sebagai konselor sekaligus tim pemasaran berdasarkan surat kerjasama LPM atau Rektor Universitas Negeri Medan dengan Dinas Pendidikan Kota Medan, Kota Binjai, Kabupaten Deli Serdang, Kabupaten Tanah Karo, Kabupaten Langkat dan dikembangkan di Kabupaten/Kota lainnya.

2. Produksi, proses produksi pada COCE setelah terjadi MoU dengan sekolah dimulai dari pada Tahap 1, menyampaikan panduan mutu pelayanan di COCE berisi pelayanan tentang peminatan, konseling, dan bimbingan belajar. Tahap 2, klien yang ingin menentukan pilihan minat diberikan instrumen angket peminatan, tes psikologi. Bagi klien yang ingin mendapatkan pelayanan bimbingan belajar dimulai dengan pengukuran mutu dan masalah belajar. Tahap 3, hasil pengukuran angket peminatan, dan tes psikologi dijadikan dasar penentuan minat. Hasil penetapan tepat klien masuk kelompok belajar. Klien yang merasa tidak tepat dilaksanakan layanan konseling. Tahap 4, bagi klien yang mengalami kesulitan belajar diberi bantuan belajar untuk masing-masing bidang studi ujian nasional. Setelah enam bulan diberi layanan konseling atau bimbingan belajar. Hasil konseling dinilai dengan alat penilaian jangka pendek (Laijapen). Hasil bimbingan belajar dilihat dari score perolehan klien pada tes bidang studi yang di ujian nasional. Kriteria keberhasilan program, jika prestasi dan proses belajar klien semakin meningkat. Jumlah siswa yang mengalami kesulitan belajar berkurang.

3. Pemasaran, klien yang akan mengikuti program COCE yaitu siswa SD, SLTP, SLTA, dan PT di Kota Medan, Kabupaten Tanah Karo, Binjai, Deli Serdang, Asahan, Simalungun, Langkat. Diprediksi setelah 3 tahun akan menyebar pada Kota/Kabupaten lainnya. Beberapa teknik pemasaran yang digunakan antara lain; developing relationship, pricing strategi, promotion strategi, dan positioning statement.

4. Sumber daya manusia, struktur organisasi COCE terdiri dari Direktur utama dengan latar belakang guru besar Universitas Negeri Medan dengan keahlian managemen konseling, tingkat pendidikan doktor dan telah mengikuti Pendidikan Profesi 
Konselor. Dibantu oleh 2 orang Profesor, 3 orang berpendidikan doktor, 6 orang dosen Bimbingan Konseling (BK) berpendidikan S2 dan telah mengikuti Pendidikan Profesi Konselor. Pegawai marketing 30 orang guru BK berpendidikan S1 dan telah selesai Pendidikan Profesi Konselor. Selanjutnya manager pemasaran 1 orang berpendidikan doktor ekonomi, manager keuangan 1 orang berpendidikan magister ekonomi, 1 orang manager operasional berpendidikan magister pendidikan dan berpendidikan profesi konselor, 2 orang staf adminstrasi berpendidikan S1, 1 orang staf keuangan berpendidikan S1. Kompetensi semua sumber daya saling melengkapi satu dengan lainnya

5. Fasilitas, kegiatan COCE dilaksanakan di gedung perpustakaa lama Universitas Negeri Medan lantai 1 yang memiliki ruang kantor 1 ruang, ruangan kelas 1 ruang, ruang bimbingan kelompok 4 ruang, dan ruang konseling individual 6 ruang. Sofware pengolahan data tes inteligensi, bakat, dan minat. Sofware pengukuran mutu dan masalah belajar.

Mutu pelaksanaan program, program COCE mendapat dukungan bapak Rektor, Warek 1, Warek II, dan staf keuangan Universitas Negeri Medan. Program ini merupakan program pertama di Universitas Negeri Medan dengan keterlibatan semua pihak di atas menjadi model bagi Universitas Negeri Medan mengembangkan usaha-usaha yang lain. Struktur organisasi COCE diketuai oleh direktur utama Prof. Dr. Rosmala Dewi, M.Pd. Kons, manager tes dipimpin oleh Prof. Dr. Sri Milfayetty, manager Keuangan dipimpin oleh Muhammad Bukhori Dalimunthe, S.Pd, M.Si, dan manager pemasaran dipimpin oleh Dr. Muhammad Fitri Ramadhana, M.Si. Tim COCE melaksaksanakan 5 prinsip managemen mutu yaitu ; (1) fokus pada pelanggan, (2) dikerjakan dengan benar, (3) komunikasi dan pendidikan, (4) diukur dan dicatat, (5) dikerjakan bersama.

\section{HASIL DAN PEMBAHASAN}

Hasil capaian COCE selama 2 tahun pelaksanaan kegiatan pengabdian mengalami pasang surut dalam memasarkan produk hingga pelaksanaan kegiatan tes yang dilakukan di sekolah, kampus, dan Dinas Pendidikan Kabupaten/Kota. Pemasaran produk dilakukan diberbagai dinas pendidikan, sekolah, dan lembaga lainnya. Pemasaran yang sudah dilakukan ke Dinas Pendidikan Kota Medan, Dinas Pendidikan Kabupaten Deli serdang, Dinas Pendidikan Kota Binjai, Dinas Pendidikan Kabupaten Serdang Bedagai, Dinas Pendidikan Kabupaten Simalungun, Dinas Pendidikan Kabupaten Karo, Dinas Pendidikan Kabupaten Asahan, Lembaga Kepribadian On the Stage, STIE IBBI Medan, dan sekolah yang berada di dalam maupun luar Kota Medan. Pada Tabel 1 dan Tabel 3 dapat dilihat pelayanan COCE selama tahun 2015 dan 2016.

Tabel 1. Pelayanan COCE Tahun 2015.

\begin{tabular}{|l|l|c|r|}
\hline \multicolumn{1}{|c|}{ Tanggal } & \multicolumn{1}{|c|}{ Jenis Layanan Tahun 2015 } & Peserta & Penerimaan \\
\hline 15 Januari & Psiko Tes Untuk Lanjutan Studi Siswa MAN 1 Medan & 208 & 7.488 .000 \\
\hline 17 Januari & Psiko Tes untuk Peminatan SMP N 6 Binjai & 280 & 11.200 .000 \\
\hline 04 Februari & Psiko Tes untuk lanjutan studi siswa SMA Negeri 1 Tanjung Morawa & 34 & 1.530 .000 \\
\hline 26 Maret & Psiko Tes untuk peminatan sisw SMA Negeri 13 Medan & 436 & 19.947 .000 \\
\hline 26 Maret & Psiko Tes siswa MTS GUPPI Islamyah & 91 & 4.095 .000 \\
\hline 07 April & Psiko Tes siswa SMP/SMA/SMK/ MA Muhammadiyah & 22 & 1.006 .500 \\
\hline 07 April & Psiko Tes Alumni Mahasiswa Universitas Negeri Medan & 46 & 920.000 \\
\hline 30 Juni & Psiko Tes siswa SMA Negeri 1 Sei Suka & 317 & 14.502 .750 \\
\hline 04 Juli & Psiko Tes MAN Kisaran & 284 & 13.038 .750 \\
\hline 15 Juli & Psiko Tes siswa Asisi Siantar & 155 & 6.757 .500 \\
\hline 23 Juli & Psiko Tes siswa SMA Swasta St. Petrus medan & 118 & 5.398 .500 \\
\hline 25 Juli & Psiko Tes siswa SMA Negeri 1 Sunggal & 407 & 17.425 .000 \\
\hline 27 Juli & Psiko Tes siswa SMA Negeri 1 Kabanjahe & 316 & 14.640 .000 \\
\hline 10 Agustus & Psiko Tes siswa SMA N Sei Balai & 105 & 4.803 .750 \\
\hline 11 Agustus & Layanan konsultasi orang tua di MAN Kisaran & 18 & non profit \\
\hline 11 Agustus & Layanan informasi tentang hasil tes di MAN Kisaran & 219 & non profit \\
\hline 11 Agustus & Layanan Bimbingan kelompok bagi siswa MAN Kisaran & 10 & non profit \\
\hline 04 September & Layanan informasi untuk guru-guru SMA St.Petrus Medan & 16 & non profit \\
\hline & Total & $\mathbf{4 . 1 2 7}$ & $\mathbf{1 2 2 . 7 5 2 . 7 5 0}$ \\
\hline
\end{tabular}

Jumlah seluruh klien yang memperoleh pelayanan pada tahun 2015 sebanyak 4.127 klien yang terdiri dari 3.864 profit dan 263 non profit. Hasil kegiatan di tahun 2015 melebihi target yang ditetapkan sebanyak 3.640 klien. Sedangkan jumlah pendapatan yang diperoleh dari masyarakat sebanyak Rp. 122.752.750. Target laba kotor/gross profit tahun 2015 sebesar Rp. 60.050.000, ternyata capaian yang diperoleh COCE sebesar Rp. 111.799.250. Begitu juga dengan operating profit margin yang ditargetkan pada tahun 2015 sebesar 35,96\%, ternyata capaian yang diperoleh sebesar 91,07\%. Keseluruhan aliran kas, perhitungan B/C ratio, titik impas pada tahun 2015 menunjukkan bahwa COCE merupakan unit bisnis 
yang feasible dan layak untuk dikembangkan menjadi unit usaha di Universitas Negeri Medan.

Tabel 2. Operating Profit Margin Tahun 2015.

\begin{tabular}{|l|r|r|}
\hline \multicolumn{1}{|c|}{ Keterangan } & \multicolumn{1}{c|}{ Target } & \multicolumn{1}{c|}{ Capaian } \\
\hline Total penerimaan & 167.000 .000 & 122.752 .750 \\
\hline Total biaya & 106.950 .000 & 10.953 .500 \\
\hline Laba kotor & 60.050 .000 & 111.799 .250 \\
\hline Operating profit margin & $35,96 \%$ & $91,07 \%$ \\
\hline
\end{tabular}

Tabel 3. Pelayanan COCE Tahun 2016.

\begin{tabular}{|l|l|r|r|}
\hline \multicolumn{1}{|c|}{ Tanggal } & \multicolumn{1}{|c}{ Jenis Layanan Tahun 2016 } & Peserta & Penerimaan \\
\hline 10 Januari & Psiko tes untuk lanjutan studi di Perguruan Tinggi siswa MAN 1 Medan & 197 & 7.880 .000 \\
\hline 25 Februari & Psiko tes untuk peminatan siswa SMAN 14 Medan & 311 & 14.355 .000 \\
\hline 12 Maret & Layanan konsultasi orang tua di SMA Negeri 14 Medan & 277 & non profit \\
\hline 21 Mei & Psiko tes untuk peminatan siswa MAN Kisaran Kabupaten Asahan & 342 & 24.200 .000 \\
\hline 25 Juni & Psiko tes untuk peminatan siswa MAN 1 Medan & 507 & 20.280 .000 \\
\hline 27 Juni & Psiko tes untuk peminatan siswa SMAN Sei Suka Kabupaten Batubara & 320 & 20.800 .000 \\
\hline 17 Juli & Layanan konsultasi orang tua di SMA Negeri Sei Suka Kabupaten Batubara & 293 & non profit \\
\hline 20 Juli & Psiko tes untuk peminatan siswa SMAN Negeri 1 Sunggal Kabupaten & 359 & 14.360 .000 \\
& Deliserdang & 103 & 5.150 .000 \\
\hline 21 Juli & Psiko tes untuk peminatan siswa SMA Swasta Santo Petrus Medan & 352 & 21.120 .000 \\
\hline 22 Juli & Psiko tes untuk peminatan siswa SMAN 1 Kabanjahe Kabupaten Karo & 415 & 24.900 .000 \\
\hline 22 Juli & Psiko tes untuk peminatan siswa SMAN 1 Berastagi Kabupaten Karo & 61 & 2.745 .000 \\
\hline 23 Juli & Psiko tes untuk penentuan bekerja atau berwirausaha bagi mahasiswa STIE & & \\
\hline 11 Agustus & Layanan informasi tentang hasil tes di SMA Swasta Santo Petrus Medan & 86 & non profit \\
\hline 11 Agustus & Layanan bimbingan kelompok bagi siswa & 18 & non profit \\
\hline 20 Agustus & Psiko tes untuk bakat dan peminatan siswa SMP dan SMA di On the Stage & 18 & 1.500 .000 \\
\hline \multicolumn{1}{|c}{ Total } & $\mathbf{3 . 6 5 9}$ & $\mathbf{1 5 7 . 2 9 0 . 0 0 0}$ \\
\hline
\end{tabular}

Pada tahun 2016 jumlah jumlah pelaksanaan pelayanan COCE sebanyak 15 kegiatan, dimana kegiatan COCE tahun 2016 lebih sedikit jika dibandingan kegiatan pada tahun 2015 sebanyak 18 kegiatan. Pada Tabel 3 diuraikan secara rinci pelayanan COCE selama tahun 2016.

Jumlah klien yang memperoleh pelayanan COCE pada tahun 2016 berjumlah 3.659 klien yang terdiri dari 2.985 profit dan 674 non profit. Klien berasal dari siswa, mahasiswa dan masyarakat umum. Kegiatan COCE di tahun 2016 belum mencapai target yang ditetapkan sebanyak 4.000 klien. Begitu juga jumlah penerimaan yang diperoleh dari pelaksanaan pelayanan sebanyak Rp. 157.290.000. Penerimaan yang diperoleh COCE di tahun 2016 belum mencapai target yang ditetapkan.

Tabel 4. Operating Profit Margin Tahun 2016.

\begin{tabular}{|l|r|r|}
\hline \multicolumn{1}{|c|}{ Keterangan } & \multicolumn{1}{c|}{ Target } & \multicolumn{1}{c|}{ Capaian } \\
\hline Total penerimaan & 238.365 .000 & 157.290 .000 \\
\hline Total biaya & 181.450 .833 & 20.453 .000 \\
\hline Laba kotor & 56.914 .167 & 136.837 .000 \\
\hline $\begin{array}{l}\text { Operating profit } \\
\text { margin }\end{array}$ & $23,87 \%$ & $86,99 \%$ \\
\hline
\end{tabular}

Target laba kotor/gross profit tahun 2016 sebesar Rp. 56.914.167, ternyata capaian COCE sebesar Rp. 136.837.000 melebihi target pencapaian laba kotor. Begitu juga operating profit margin ditargetkan sebesar $23,87 \%$, ternyata capaian sebesar $86,99 \%$. Data keuangan menunjukkan bahwa unit usaha COCE berjalan dengan baik dan dapat dilanjutkan pada tahun berikutnya.

Aktivitas pelayanan unit usaha COCE tidak semua harus membayar, pelayanan yang bersifat gratis banyak dilakukan bagi siswa, mahasiswa dan masyarakat yang membutuhkan, sepenuhnya untuk membantu individu yang bermasalah terutama kegiatan konseling. Setelah selesai hasil tes psikologi dilaporkan, beberapa sekolah seperti SMA Negeri 14 Medan, SMA Negeri Sei Suka Kabupaten Batubara, dan SMA Swasta Santo Petrus Medan meminta bantuan pelaksanaan konseling tindak lanjut dari data hasil tes psikologi, tim menyusun program layanan konseling sesuai data yang diperoleh secara gratis. Ada beberapa layanan yang dilakukan antara lain; (1) pelayanan informasi tentang makna hasil tes pada orang tua siswa; (2) layanan konsultasi untuk orang tua tentang anaknya; (3) pelayanan bimbingan kelompok bagi siswa yang bermasalah dalam belajar; dan (4) dilanjutkan oleh guru pembimbing di sekolah, dengan permasalahan siswa sebagai berikut: (a) materi pelajaran tidak diulang, (b) tidak membuat pertinggal tugas yang diserahkan kepada guru, (c) tidak berusaha melengkapi bahan pelajaran, (d) tidak percaya diri 
dalam kegiatan baik di dalam dan di luar kelas, (e) tidak mengulang pelajaran untuk memahami pelajaran berikutnya, (f) tidak membuat pertanyaan dan menjawabnya sebagai cara memahami materi pelajaran, (g) tidak membentuk atau menyelenggarakan kelompok untuk menunjang kegiatan belajar, dan (h) tidak menulis intisari pelajaran.

Berdasarkan pengukuran masalah belajar siswa ditemukan berbagai masalah keterampilan belajar siswa saat ini menonjol dialami siswa. Keterampilan belajar yang dimaksud pada proses mengikuti pelajaran, mengulang pelajaran, mencatat pelajaran, melengkapi bahan belajar, sebagian besar siswa tidak melakukannya. Akibatnya kondisi siswa cemas dengan hasil belajarnya, tidak nyakin dengan usaha yang telah dilakukan. Jika dihubungkan dengan hasil tes psikologi sesuai dengan keadaan kemampuan siswa rendah.

Berdasarkan data psiko tes yang dilakukan selama tahun 2015 dan 2016 pada umumnya untuk kemampuan minat klien pada Ilmu Alam dan Matematika mencapai $30 \%$, sedangkan Ilmu Sosial $70 \%$. Data ini berakibat pemerataan jam mengajar yang diperoleh guru-guru tidak merata, dimana di setiap sekolah jumlah kelas Ilmu Alam dan Matematika lebih banyak daripada kelas Ilmu Sosial. Sehingga keputusan akhir penentuan penjurusan siswa dirundingkan kembali oleh Tim COCE bersama guru bimbingan konseling dan kepala sekolah.

Hasil data psiko tes diperoleh nilai IQ dan bakat siswa bervariasi antara siswa yang berasal dari daerah kota, gunung, dan pantai. Data psiko tes menunjukkan hal yang sama dengan hasil penelitian yang diungkapkan oleh Dewi dkk (2016) menjelaskan bahwa terdapat perbedaan kemampuan bahasa dan berhitung siswa yang berasal dari perkotaan, gunung, dan pantai. Lebih lanjut Dewi dkk (2016) menjelaksan bahwa kemampuan skolastik siswa yang berasal dari gunung lebih tinggi dari pada siswa yang berasal dari daerah perkotaan dan pantai. Data yang diperoleh dari pelayanan yang diberikan akan sangat membantu klien dan masyarakat untuk dapat mengetahui perkembangan belajar dan masalah yang dihadapi oleh klien.

\section{KESIMPULAN}

Berdasarkan hasil dan pembahasan yang telah diuraikan, maka dapat disimpulkan bahwa;

1. Jumlah klien yang diperoleh pada tahun 2015 sebanyak 4.127 klien dan tahun 2016 sebanyak 3.659 klien.

2. Tim COCE melakukan pelayanan secara gratis terutama bagi siswa, mahasiswa, pegawai,dan orang tua atau wali yang membutuhkan pelayanan konseling. Banyaknya pelayanan non profit yang dilakukan pada tahun 2015 berjumlah 263 klien dan tahun 2016 sebanyak 674 klien.

3. Capaian operaitng profit margin pada tahun 2015 sebesar 91,07\% dan tahun 2016 sebesar 86,99\%. Operaitng profit margin yang diperoleh COCE melebihi dari target.

4. Unit usaha COCE Universitas Negeri Medan layak untuk dikembangkan menjadi unit bisnis yang dikelola oleh dosen dan mahasiswa sebagai income generate kampus serta sebagai wadah pelayanan kepada masyarakat untuk menyelesaikan permasalahan dan perkembangan dalam belajar.

\section{UCAPAN TERIMA KASIH}

Ucapan terima kasih penulis tujukan kepada Direktorat Riset dan Pengabdian Masyarakat Kementerian Riset, Teknologi dan Pendidikan Tinggi yang telah memberikan pendanaan dan kepercayaan kepada Tim melaksanakan Program Ipteks Kreativitas Inovasi Kampus selama 3 tahun. Serta ucapan terima kasih kepada Lembaga Pengabdian Masyarakat Universitas Negeri Medan yang telah membantu Tim untuk penyelenggaraan pengabdian kepada masyarakat.

\section{DAFTAR PUSTAKA}

Antaranews. (2016). Mahasiswa UMSU Bunuh Dosen di Kamar Mandi. Diakses 17 Desember 2016. http://www.antaranews.com/berita/558581/ mahasiswa-umsu-bunuh-dosen-di-kamarmandi.

Dewi, Rosmala. (2012). Pengukuran Mutu dan Masalah Belajar Mahasiswa. Universitas Negeri Medan: Unit Pelayanan Bimbingan Konseling.

(2013). Pengembangan Model Pelayanan Konselor Sebaya Berkarakter Melalui Strategi BMB3 di Universitas Negeri Medan. Hasil penelitian. Universitas Negeri Medan.

Dewi, Rosmala., Zaimah, R., Dalimunthe, M.B., \& Rahmadana, M.F. (2016). Comparative Study of Student Verbal Reasoning and Numerical Reasoning between Urban, Coastal and Highlands Areas in North Sumatra. Developing Country Studies, 6 (10), 146-150.

Kompas. (2016). Orangtua dan Murid yang Pukul Guru di Makassar Jadi Tersangka. Diakses 17 Desember 2016. http://regional.kompas.com/read/2016/08/11/10 493651/orangtua.dan.murid.yang.pukul.guru.di .makassar.jadi.tersangka. 